\title{
Incidental Isolated Pancreatic Hydatid Cyst
}

\author{
İnsidental İzole Pankreas Kist Hidatiği
}

\section{Abdullah Kısaoğlu1', Bünyami Özoğul' ${ }^{1}$ Sabri Selçuk Atamanalp¹, Berhan Pirimoğlu², Bülent Aydınlı', Ercan Korkut ${ }^{1}$}

1Department of General Surgery, Atatürk University Faculty of Medicine, , Erzurum, Turkey

${ }^{2}$ Department of Radiology, Atatürk University Faculty of Medicine, Erzurum, Turkey

\begin{abstract}
Isolated pancreatic hydatid cysts are a rare parasitic disease even in endemic areas. It is difficult to discriminate primary pancreatic hydatid cysts from other cystic and solid lesions of the pancreas. This is a case report of an incidental isolated pancreatic hydatid cyst. A heterogeneous cystic lesion in the body of the pancreas was identified on magnetic resonance imaging of a patient previously diagnosed patient with cholelithiasis, and because of the malignant possibility of the lesion, splenectomy with distal pancreatectomy and cholecystectomy was performed. The histopathologic diagnosis was reported as a hydatid cyst. Pancreatic hydatid cysts should be kept in mind in the differential diagnosis of pancreatic pseudocysts and cystic malignancies. (Turkiye Parazitol Derg 2015; 39: 75-7)
\end{abstract}

Keywords: Hydatid cyst, incidental, pancreas

Received: 19 Temmuz 2013

Accepted: 4 Eylül 2014

\section{ÖZET}

İzole pankreas kist hidatiği endemik bölgelerde bile çok nadir görülen paraziter hastalıktır. Sadece pankreasta yerleşen primer kist hidatiklerin pankreasın diğer kistik ve solid lezyonlarından ayııımı güçtür. Yazımızda tesadüfen tespit edilen izole pankreas kist hidatiği vakası sunulmuştur. Kolelitiazisi mevcut olan hastaya çekilen magnetic resonance imaging (MRI)'de pankreas gövdesinde heterojen içerikli kistik lezyon tespit edilmesi üzerine mevcut lezyonun pankreasın kistik malignitesi olduğu düşünülerek hastaya splenektomi ile distal pankreatektomi ve kolesistektomi yapılmıştı. Histopatolojik tanı kist hidatik şeklinde rapor edilmiştir. Pankreas psödokistlerinin ve kistik malignitelerin ayırıcı tanısında pankreas kist hidatiği akılda tutulmalıdır. (Turkiye Parazitol Derg 2015; 39: 75-7)

Anahtar Sözcükler: Hidatik kist, pankreas, rastlantısal

Geliş Tarihi: 19 Temmuz 2013

Kabul Tarihi: 4 Eylül 2014 \footnotetext{
Erzurum, Turkey.

Phone: +90 4422317566 E-mail: kisaoglu.a@gmail.com

DOI: 10.5152/tpd.2015.3293

CTelif hakkı 2015 Türkiye Parazitoloji Derneği - Makale metnine www.tparazitolderg.org web sayfasından ulaşılabilir.

CCopyright 2015 Turkish Society for Parasitology - Available online at www.tparazitolderg.org
}

Address for Correspondence / Yazışma Adresi: Dr. Abdullah Kısaoğlu, Department of General Surgery, Atatürk University Faculty of Medicine, 


\section{INTRODUCTION}

Hydatid cysts are an important health problem in endemic areas. Although this disease usually involves the liver, it may be seen in any organ. Hydatid cysts of the liver and lungs make up $90 \%$ of cases $(1,2)$. However, pancreatic involvement is quite rare and pancreatic hydatid cysts have been reported as being less than $1 \%(2,3)$. A preoperative definite diagnosis of isolated pancreatic hydatid cysts, which are rare worldwide, is difficult despite radiological imaging methods. Pancreatic hydatid cysts should be kept in mind in the differential diagnosis of pancreatic cystic masses in endemic regions. We present a case of a pancreatic hydatid cyst in a patient in whom we incidentally detected a cystic mass in the pancreas. Written informed consent was obtained from the patient who participated in this case.

\section{CASE REPORT}

Cholelithiasis was diagnosed on a control abdominal ultrasonography (USG) in a 58-year-old female patient who developed abdominal pain during preparation for renal transplantation due to chronic renal failure. Her physical examination revealed tenderness in the right upper quadrant and epigastrium and she did not have fever or jaundice. Her vital findings were normal. She had been using antihypertensive drugs for 10 years. Laboratory examination findings were as follows: alkaline phosphatase (ALP) $191 \mathrm{U} / \mathrm{L}$ (normal value: <120 U/L), gamma-glutamyl transferase (GGT) $241 \mathrm{U} / \mathrm{L}$ (normal value: <49 U/L), blood urea nitrogen 63.5 $\mathrm{mg} / \mathrm{dL}$ (normal value: $6-22 \mathrm{mg} / \mathrm{dL}$ ), creatinine $9.98 \mathrm{mg} / \mathrm{dL}$ (normal value: 0.8-1.4 mg/dL), C-reactive protein $86.7 \mathrm{mg} / \mathrm{L}$ (normal value: $<5 \mathrm{mg} / \mathrm{L}$ ), and erythrocyte sedimentation rate $75 \mathrm{~mm} /$ hour. Other laboratory tests were normal. Abdominal magnetic resonance imaging (MRI), which was obtained because of the elevated ALP and GGT enzyme levels, revealed a heterogeneous cystic lesion measuring $41 \times 34 \mathrm{~mm}$, with relatively regular contours (Figure 1a, b). Intrahepatic bile ducts, extrahepatic bile ducts, and the common bile duct were normal. There were no pathologies in any other intra-abdominal organs. Because this cystic lesion detected on MRI was evaluated as a possible cystic malignancy of the pancreas, the patient underwent surgery. On exploration, the lesion was found to be adherent to surrounding tissues, it measured $5 \times 3 \mathrm{~cm}$ in diameter, and was located in the corpocaudal part of the pancreas adjacent to the vena mesenterica superior. Splenectomy, distal pancreatectomy, and cholecystectomy were performed following caudal resection of pancreas with the mass lesion. No postoperative complications developed. The histopathologic examination revealed that the lesion was a hydatid cyst. A treatment of daily $800 \mathrm{mg}$ of albendazole was planned for 3 months postoperatively and the patient was discharged from the hospital with recovery.

\section{DISCUSSION}

Hydatid cysts are an endemic problem in Mediterranean countries, New Zealand, South America, South East, Far East Asia, and the Middle East (4). Approximately 2/3 hydatid cysts are located in the liver because it is the first passage site of Echinococcus granulosus eggs ingested via the digestive system. Hydatid cyst infestation may develop in any organ, although the lungs are the second most common location site of the parasite $(5,6)$. The literature, which has reported cases of pancreatic hydatid cysts as being seen less than $1 \%$, states that the caput pancreaticus is involved the most (57\%), followed by the corpus (24\%) and the caudal (19\%) part of the pancreas $(1,2,7$, 8). Clinical manifestations vary depending on the anatomic localization of the cyst and potential complications, such as infection; ruptured, biliary, or intestinal fistula; vascular thrombosis; and acute or chronic pancreatitis (9). Symptoms arise because of pressure on neighboring tissues as the size of the cyst enlarges. Complaints such as abdominal pain, distention, and nausea may be seen although patients may be asymptomatic for a long time (10). Our patient had right upper quadrant pain and epigastric pain. Elevated enzyme levels along with a diagnosis of cholelithiasis were suggestive of gallbladder and bile duct disease. However, the lesion incidentally detected in the body of the pancreas was perhaps the main cause of the pain. It is reported that obstructive jaundice may occur because of pressure on bile ducts in hydatid cysts located at the head of the pancreas and acute or chronic pancreatitis may occur in cases where pressure is created on the pancreatic duct $(11,12)$. Our patient did not have obstructive jaundice or pancreatitis. Also, it has been reported that $9.3 \%$ of these cysts spontaneously perforate or rupture into the peritoneal space. (13).

Diagnosis may be made on USG, computed tomography (CT), and MRI. USG may reveal membrane detachment, presence of daughter cysts, multivesicular cyst structure surrounded by a clear wall, and hydatid structures with a calcified thick wall depending on the type of cyst $(2,14)$. The location, diameter, and number of cysts are clearly visualized on CT. CT also provides information about the relationship between the cyst and large vessels and bile ducts and wall calcification (15). However, MRI is more valuable for the detection of cystobiliary fistula (16). Although it is easy to detect cystic lesions in the pancreas, these methods have a limited sensitivity for the diagnosis of pancreatic hydatid cysts and preoperative definite diagnosis may not be made. Among these methods, USG has the highest diagnostic accuracy $(93 \%-98 \%)$ for abdominal hydatid cysts $(8,14)$. However, definite diagnosis is made with surgery and histopathological examinations (8). Specific laboratory tests are not available for the diagnosis of pancreatic hydatid cysts. The Casoni skin test is an immunological test with low sensitivity. Indirect immunofluorescence assay has a high specificity and sensitivity depending on the localization of the cyst. Enzyme-linked immunosorbent assay, indirect agglutination, and indirect hemagglutination are frequently used serologic tests (17). We did not perform these tests because we interpreted the cystic mass in the pancreas as a possible malignancy, although we live in an endemic area for hydatid cysts. We did not perform CT or a detailed USG either.

Treatment options for this disease include medical therapy, percutaneous drainage, and surgical therapy. Sensitivity to albendazole therapy for 4-6 months has been reported as being 60\%$90 \%$ in various series (10). USG-guided percutaneous drainage, which is debated because of the risks of anaphylaxis and peritoneal spread, is still a treatment option. Although its effectiveness has been reported as being $100 \%$ in many publications, this method is recommended especially for Gharbi type I and II cases. Medical therapy before and after drainage reduces mor- 


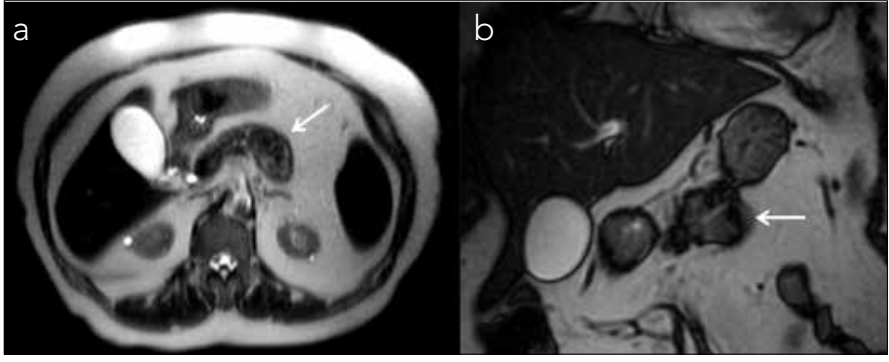

Figure 1. a, b. Axial (a) and coronal (b) T2-weighted magnetic resonance images show a well-demarcated hypointense cystic lesion with heterogeneous liquid content (arrows)

bidity and recurrence $(18,19)$. Pericystectomy as a surgical method is an ideal method despite a relatively high complication rate. The total evacuation of cystic content is recommended in patients who do not undergo pericystectomy. Although the space may be closed by omentoplasty and capitonnage, external or internal drainage may also be performed. Another important issue in pancreatic hydatid cysts is the maintenance of pancreatic functions following surgery. Although distal pancreatectomy is preferred in cases that are located in the body and tail of the pancreas, cyst excision and internal or external drainage is preferred in cases located in the processus uncinatus $(5,6,19)$. We performed distal pancreatectomy and splenectomy because we primarily interpreted the lesion located in the corpocaudal part of the pancreas as a malignancy.

Although pancreatic hydatid cysts are rare, they should be kept in mind in the differential diagnosis of pancreatic pseudocysts and cystic malignancies of the pancreas, particularly in endemic areas. A preoperative diagnosis may not be possible despite imaging methods and laboratory tests. The ideal treatment option is excision of the cyst to prevent intra-abdominal spread and albendazole therapy thereafter.

Informed Consent: Written informed consent was obtained from the patient.

Peer-review: Externally peer-reviewed.

Author Contributions: Consept - A.K., B.O.; Design - A.K., B.A.; Supervision - S.S.A.; Funding - A.K.; Materials - B.O.; Data Collection and/or Processing - S.S.A., B.A.; Analysis and/or Interpretation - B.P., E.K.; Literature Review - B.P., E.K.; Writer A.K.; Critical Review - B.A.

Conflict of Interest: No conflict of interest was declared by the authors.

Financial Disclosure: The authors declared that this study has received no financial support.

Hasta onamı: Yazılı hasta onamı hastadan alınmıştır.

Hakem Değerlendirmesi: Dış Bağımsız.
Yazar Katkıları: Fikir - A.K., B.O.; Tasarım - A.K., B.A.; Denetleme - S.S.A.; Kaynaklar - A.K.; Malzemeler - B.O.; Veri Toplanması ve/ veya işlemesi - S.S.A., B.A.; Analiz ve/veya Yorum - B.P., E.K.; Literatür taraması - B.P., E.K.; Yazıyı Yazan - A.K.; Eleştirel inceleme - B.A.

Çıkar Çatışması: Yazarlar çıkar çatışması bildirmemişlerdir.

Finansal Destek: Yazarlar bu çalışma için finansal destek almadıklarını beyan etmişlerdir.

\section{REFERENCES}

1. Dziri C. Hydatid disease--continuing serious public health problem: introduction. World J Surg 2001; 25: 1-3. [CrossRef]

2. Khiari A, Mzali R, Ouali M, Kharrat M, Kechaou MS, Beyrouti MI. Hydatid cyst of the pancreas. Apropos of 7 cases. Ann Gastroenterol Hepatol 1994; 30: 87-91.

3. Rodríguez Vargas J, Arroyo Carrera I, Pitarch Esteve V. Pancreatic hydatid cysts. Cir Pediatr 1992; 5: 46-7.

4. Echenique-Elizondo $\mathrm{M}$, Amondarain Arratíbel JA. Hydatid disease of the pancreas. JOP 2004; 5: 51-2.

5. Krige JE, Mirza K, Bornman PC, Beningfield SJ. Primary hydatid cysts of the pancreas. S Afr J Surg 2005; 43: 37-40.

6. Schiano di Visconte M, Lombardo C, Munegato G. Pancreatic echinococcosis. Chir Ital 2003; 55: 585-90.

7. Ousadden A, Elbouhaddouti H, Ibnmajdoub KH, Mazaz K, Aittaleb K. Primary hydatid cyst of the pancreas with a hepatic pedicule compression. Cases J 2009; 2: 201. [CrossRef]

8. Shah OJ, Robbani I, Zargar SA, Yattoo GN, Shah P, Ali S, et al. Hydatid cyst of the pancreas. An experience with six cases. JOP 2010; 11: 575-81.

9. Hammad A, Mentouri B. Acute pancreatitis in Algeria. Report of 221 Cases. Am J Sur 1985; 149: 709-11. [CrossRef]

10. Safioleas MC, Moulakakis KG, Manti C, Kostakis A. Clinical considerations of primary hydatid disease of the pancreas. Pancreatology 2005; 5: 457-61. [CrossRef]

11. Yattoo GN, Khuroo MS, Zargar SA, Bhat FA, Sofi BA. Case report: Percutaneous drainage of the pancreatic head hydatid cyst with obstructive jaundice. J Gastroenterol Hepatol 1999; 14: 931-4. [CrossRef]

12. Regan JK, Brown RD, Marrero JA, Malik P, Rosenberg F, Venu RP. Chronic pancreatitis resulting from primary hydatid disease of the pancreas: a case report and review of the literature. Gastrointest Endosc 1999; 49: 791-3. [CrossRef]

13. Köylüoğlu G, Oztoprak I. Unusual presentation of pancreatic hydatid cyst in a child. Pancreas 2002; 24: 410-1. [CrossRef]

14. Balik AA, Celebi F, Başoglu M, Oren D, Yildirgan I, Atamanalp SS. Intra-abdominal extrahepatic echinococcosis. Surg Today 2001; 31: 881-4. [CrossRef]

15. Missas S, Gouliamos A, Kourias E, Kalovidouris A. Primary hydatid disease of the pancreas. Gastrointest Radiol 1987; 12: 37-8. [CrossRef]

16. Stojkovic M, Rosenberger K, Kauczor HU, Junghanss T, Hosch W. Diagnosing and staging of cystic echinococcosis: how do CT and MRI perform in comparison to ultrasound? PLoS Negl Trop Dis 2012; 6: e1880.

17. Biava MF, Dao A, Fortier B. Laboratory diagnosis of cystic hydatic disease. World J Surg 2001; 25: 10-4. [CrossRef]

18. Bosanac ZB, Lisanin L. Percutaneous drainage of hydatid cyst in the liver as a primary treatment: review of 52 consecutive cases with long-term follow-up. Clin Radiol 2000; 55: 839-48. [CrossRef]

19. Menezes da Silva A. Hydatid cyst of the liver-criteria for the selection of appropriate treatment. Acta Trop 2003; 85: 237-42. [CrossRef] 